\title{
PEDAGOGICAL DIGITAL COMPETENCE AND ITS ACQUISITION IN A TEACHER EDUCATION PROGRAMME
}

\author{
Katrina Elizabete Purina-Bieza \\ University of Latvia, Latvia
}

\begin{abstract}
Pedagogical digital competence can be characterised as an opportunity to improve the pedagogical process by using digital technologies in professional activities (From, 2017). In 2017, the European Commission presented a model of pedagogical digital competence, viewing teacher professional pedagogical competence, as well as demonstrating their impact and developing students' digital literacy (Redecker, 2017). The aim of this study is to research pedagogical digital competence and its planned acquisition in one teacher professional bachelor study programme.

As a result of the analysis of the theoretical literature, the concept of digital literacy and pedagogical competence was defined, and the understanding of pedagogical digital competence was provided. The empirical research looked at 1553 learning outcomes advertised in 201 course descriptions of one teacher professional bachelor study programme and analysed them from the perspective of pedagogical digital competence. As a result of the study, a concept-model of pedagogical digital competence was developed.
\end{abstract}

Keywords: concept-model, digital literacy, pedagogical competence, pedagogical digital competence, teacher education.

\section{Introduction}

As a result of the COVID-19 pandemic, national education systems are under severe pressure. Most European countries have chosen to terminate full-time education in schools (UNESCO, COVID-19 Educational Disruption and Response), therefore educators and practitioners are looking for new opportunities and solutions to continue and fully ensure the pedagogical process. The most common solution found is the use of digital technologies for the implementation of distance learning.

According to the data on the impact of COVID-19 on education gathered by the OECD (Reimer \& Schleiche, 2020), the greatest difficulties are seen in continuing the learning process and supporting students who are 
less independent and lack online learning skills. The most complex aspects of the distance learning process are availability of technological infrastructure, ensuring a balance between digital and screen-free activities and addressing students' emotional wellbeing. This leads to the conclusion that in the students' daily learning process there is insufficient systematic and planned digital technology usage to practice independent and self-directed learning.

In half of European countries, the only criterion for obtaining a full teacher qualification is the acquisition of initial teacher education, which attaches increased importance to the provision of high-quality and comprehensive initial teacher education (European Commission/EACEA/Eurydice, 2018). Nevertheless, higher education institutions have a key role in managing and organising the learning content and process of teacher education and the development of teacher education curriculums (European Commission/EACEA/Eurydice, 2019). Such an approach poses a risk to the balanced and equal qualitative provision of pedagogical digital competence in all teachers' professional education programmes.

The European Commission (2018) has developed a model that brings together the knowledge and skills teachers need to successfully and meaningfully integrate digital technologies in the teaching-learning process. The idea is emerging that digital competence in education it is not just a question of what technologies should be introduced in the learning process, but also of how to relate them to the content and goals of learning, making technologies a learning tool to promote higher learning outcomes and achievements (Instefjord \& Munthe, 2017). For these reasons, it is important for teacher education to take into account pedagogical digital aspects that explain how to plan and implement a technology-enhanced learning process.

Aim of the research - to analyse the concept of pedagogical digital competence and its planned acquisition in a teacher education programme.

\section{Research questions:}

1) What are the components of pedagogical digital competence that teachers needs in their work?

2) How is the acquisition of pedagogical digital competence in the teacher education programme planned?

\section{Limitations}

1. The study was conducted from the spring of 2019 to the spring of 2020.

2. Systematic literature review was conducted using articles available in the scientific database EBSCO that define digital literacy/pedagogical competence. The keywords used for the search were "defining digital literacy" 
and "pedagogical competence". In the selected articles the definitions of digital literacy or pedagogical competence were further analysed.

3. Four models found during the systemic literature review, which characterise the variations of pedagogical competence and digital literacy integration, were analysed.

4. For document analysis, the study course descriptions of the seven study sub-programmes of the professional bachelor's study programme "Teacher" were used.

\section{Method}

In the research three-stage triangulation was implemented (see Fig. 1).

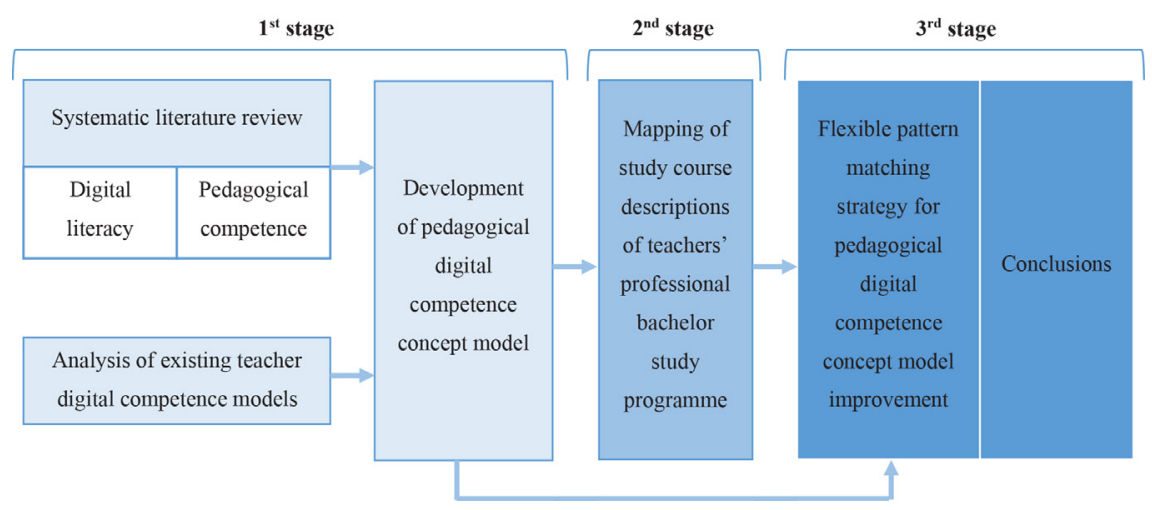

Figure 1. Research design

1. Theory triangulation (Flick, 2007), through which the concepts of digital literacy and pedagogical competence were analysed conducting systemic literature review. The results of the systematic literature review were contrasted with four models that integrate pedagogical competence and digital literacy found in the literature. As a result of the literature analysis, a pedagogical digital competence concept model was developed.

2. Triangulation of the results of document analysis with pedagogical digital competence concept model using pattern matching strategy (Johnson \& Christensen, 2012). The understanding of pedagogical digital competence included in the concept model was used to map the course descriptions of a teachers' professional bachelor study programme in the perspective of pedagogical competence and digital literacy.

3. Triangulation of the pedagogical digital competence concept model with the results of document analysis using flexible pattern matching strategy (Sinkovics, 2018). The study course description mapping was 
conducted using steps of gap/redundancy analysis (Joyner, 2016). The conclusions made from the study course mapping were again contrasted with the developed pedagogical digital competence concept model and the concept model was improved.

\section{Understanding of digital literacy and pedagogical competence}

The analysis of the theoretical literature was performed by analysing and defining

1) components of digital literacy,

2) components of pedagogical competence, and reviewing 4 existing models of pedagogical digital competence.

\section{Digital literacy}

Digital literacy is a widely used term with several analogous terms (information literacy, technology literacy, computer literacy, digital competence, digital skills) that include identical or conceptually similar content. Digital literacy focuses on individual's life, learning, work skills and abilities in the digital society (Spante et al., 2018). The concept of digital literacy, unlike the concept of digital competence, is based on the acquisition of specific skills, and is described at different levels of its acquisition (Spante et al., 2018). This makes it easier to integrate digital literacy content into the acquisition of other skills and competences. As the study integrates digital literacy into the acquisition of pedagogical competence, the concept of digital literacy has been chosen as the basis of the study, distinguishing concrete components of digital literacy (see Table 1).

Digital proficiency includes (Bieza, 2020):

1) using digital tools to master new digital technologies and ensuring their most efficient use;

2) critically using digital resources: choosing, evaluating and circumspectly applying digital technologies and media content;

3) modern skills which are a significant part of social life, requiring reflection on one's own security and responsible behaviour within the digital environment. 
Table 1. Components of digital literacy (Bieza, 2020)

\begin{tabular}{|c|c|}
\hline Basic skills & Derived skills \\
\hline \multirow[t]{2}{*}{ Usage of new technologies } & Personal growth \\
\hline & Flexibility \\
\hline $\begin{array}{l}\text { Utilisation of technological } \\
\text { potential }\end{array}$ & $\begin{array}{l}\text { Finding the most effective use of digital } \\
\text { technology }\end{array}$ \\
\hline \multirow[t]{6}{*}{ Information and media literacy } & Searching of information \\
\hline & Storing information \\
\hline & Sending information \\
\hline & Processing information \\
\hline & Demonstration of digital content \\
\hline & Creating digital content \\
\hline \multirow[t]{5}{*}{ Technology literacy } & Usage of digital tools \\
\hline & Use the potential of digital tools \\
\hline & Evaluate digital tools \\
\hline & $\begin{array}{l}\text { Understand the importance of and need for } \\
\text { digital tools }\end{array}$ \\
\hline & Creation of new solutions \\
\hline \multirow[t]{5}{*}{ Social skills } & Communication skills in the digital environment \\
\hline & Participation in social processes \\
\hline & Ability to build relationships \\
\hline & Ability to develop personal identity \\
\hline & $\begin{array}{l}\text { The ability to position oneself in the digital } \\
\text { environment }\end{array}$ \\
\hline \multirow[t]{2}{*}{ Security and responsibility } & $\begin{array}{l}\text { Responsible use of digital resources - Evaluating } \\
\text { information before continuing to use it }\end{array}$ \\
\hline & $\begin{array}{l}\text { Digital Security - The ability to protect yourself } \\
\text { from the threats of the digital environment. }\end{array}$ \\
\hline
\end{tabular}

\section{Teachers' pedagogical competence}

The concept of pedagogical competence differs from the similar concept of pedagogical competency in its understanding. The concept of pedagogical competency looks at the pedagogical process from the perspective of teachers' skills (Pekkarinen \& Hirsto, 2017). In turn, in this research, pedagogical competence is viewed from the aspect of a teacher's knowledge, attitudes and personality traits, which is included in the concept of pedagogical competence. 
Pedagogical competence can be described as a set of knowledge, skills and attitudes, that include planning and organising a student-centered and inclusive learning process based on the teacher's knowledge of the content of the subject and its teaching methodology combined with constant teacher reflection on students' learning activities and on the teacher's own pedagogical practice.

The main components of pedagogical competence are:

1) knowledge related to the teaching methodology and content of the subject, as well as knowledge about students (developmental stages and age differences, knowledge about students' individual knowledge and skills) and knowledge about the essence of the inclusive learning process:

- knowledge of the subject (Cui, 2018; Yürekli Kaynardağ, 2019)

$\diamond$ content (Soysal \& Radmard, 2018; Farinde-Wu et al., 2017)

$\checkmark$ teaching methodology (Pekkarinen \& Hirsto, 2017; Soysal \& Radmard, 2018; Ekmekçi, 2018; Kabakci Yurdakul, 2018)

- knowledge about students

$\diamond$ developmental stages and age differences (Hayes \& Filipović, 2018)

$\diamond$ knowledge about students' individual level of knowledge and skills (Soysal \& Radmard, 2018; Farinde-Wu et al., 2017)

- knowledge about implementation of an inclusive teaching-learning process (Cui, 2018; Yürekli Kaynardağ, 2019)

2) skills that a teacher acquires by practicing his/her theoretical knowledge (Pekkarinen \& Hirsto, 2017)

3) attitudes that are in accordance with the teacher's personal value system and current knowledge (Wilkins, 2008; Jons, 2008)

4) competencies that are necessary for every member of modern society (Trilling \& Fadel, 2009):

- learning skills - independent learning, critical thinking and problem solving, research skills (Pekkarinen \& Hirsto, 2017; Kabakci Yurdakul, 2018)

- creativity (use of existing solutions) and innovation (creation of new solutions)

- digital literacy - information literacy, media literacy, technology literacy (Cui, 2018; Yürekli Kaynardağ, 2019)

- career skills - adaptation skills, communication skills (Cui, 2018; Yürekli Kaynardağ, 2019), skills of productivity and leadership (Kabakci Yurdakul, 2018)

- life skills - social skills, responsibility

5) awareness and self-regulation, which promotes the pedagogues' reflection on his/her professional work and needs (Altan et al., 2019; Pekkarinen \& Hirsto, 2017) 


\section{Existing approaches for integrating digital literacy and pedagogical competence}

Digital literacy in teacher education is a widely discussed topic among researchers searching for solutions for implementing digital literacy in teacher education. There is a consensus among researchers that the solution to the problem of successful acquisition of digital literacy is an integrated approach, combining acquisition of digital literacy and pedagogical competence. The literature depicts two ways in which pedagogical competence and digital literacy are integrated:

- base of digital literacy in which teacher pedagogical competences are integrated (Krumsvik, 2011; Ottestad et al., 2014),

- base of teacher pedagogical competence in which digital literacy components are integrated (Kelentrić et al., 2017; Mishra \& Koehler, 2006; Redecker, 2017).

Teachers' digital literacy can be divided into 4 developmental stages:

1. Generic digital competence, digital skills needed for anyone in modern society (Krumsvik, 2011; Mishra \& Koehler, 2006; Ottestad \& Kelentrić Guðmundsdóttir, 2014).

2. Didactic digital competence, involving the teacher in the implementation and alteration of digital technologies in the teaching-learning process (Krumsvik, 2011; Ottestad \& Kelentrić Guðmundsdóttir, 2014, Kelentrić et al., 2017).

3. Professional digital competence, the teacher makes extensive use of digital technologies to improve and organise his/her professional work, as well as to ensure inclusive and active learning for students both in the classroom and in the digital environment (Redecker, 2017; Ottestad et al., 2014).

4. Pedagogical digital competence, based on planning, organising and evaluating the students' use of digital technologies, as well as on assessing the impact of digital technologies on the teacher's work and students' learning (Krumsvik, 2011; Ottestad et al., 2014; Redecker, 2017).

\section{Pedagogical digital competence}

Based on the literature review the author developed a pedagogical digital competence concept model, aiming to demonstrate the stages of pedagogical digital competence development and to explain how its sequential acquisition takes place. 


\section{Interrelationships between pedagogical competence and digital literacy}

The components of pedagogical competence and digital literacy were used as a basis for explaining pedagogical digital competence. Similarities between the knowledge, skills and attitudes required in both competencies were sought (see Table 2) and 7 categories of pedagogical digital competences were identified. Each category includes aspects of digital and pedagogical competence that can be integrated with each other forming pedagogical digital competence.

Table 2. Categories of pedagogical digital competence

\begin{tabular}{|c|c|c|}
\hline Category & Components of digital literacy & $\begin{array}{l}\text { Components of pedagogical } \\
\text { competence }\end{array}$ \\
\hline $\begin{array}{l}\text { Awareness and } \\
\text { self-regulation }\end{array}$ & $\begin{array}{l}\text { Being aware of the importance } \\
\text { and need for digital tools } \\
\text { Personal growth }\end{array}$ & $\begin{array}{l}\text { Awareness and self-regulation } \\
\text { Career skills }\end{array}$ \\
\hline Attitudes & $\begin{array}{l}\text { Using digital technologies } \\
\text { Evaluating digital content } \\
\text { Managing the power of digital } \\
\text { tools } \\
\text { Flexibility }\end{array}$ & $\begin{array}{l}\text { Attitudes in accordance with the } \\
\text { teacher's personal value system } \\
\text { and current knowledge }\end{array}$ \\
\hline $\begin{array}{l}\text { Knowledge } \\
\text { acquisition and } \\
\text { processing }\end{array}$ & $\begin{array}{l}\text { Information and media literacy } \\
\text { Searching for information } \\
\text { Storing information } \\
\text { Sending information } \\
\text { Processing information } \\
\text { Showcasing digital content } \\
\text { Creating digital content } \\
\end{array}$ & $\begin{array}{l}\text { Learning skills } \\
\text { Knowledge about the content of } \\
\text { the subject } \\
\text { Knowledge about diversity and } \\
\text { inclusion } \\
\text { Life skills } \\
\text { Digital literacy } \\
\end{array}$ \\
\hline $\begin{array}{l}\text { Cooperation and } \\
\text { communication }\end{array}$ & $\begin{array}{l}\text { Social skills } \\
\text { Communication skills in the } \\
\text { digital environment } \\
\text { Participation in society } \\
\text { Ability to build relationships } \\
\text { Ability to form a personal } \\
\text { identity } \\
\text { Ability to position oneself in the } \\
\text { digital environment }\end{array}$ & $\begin{array}{l}\text { Classroom management } \\
\text { skills }\end{array}$ \\
\hline Ethics & $\begin{array}{l}\text { Security and liability } \\
\text { Responsible use of digital } \\
\text { resources } \\
\text { Digital security } \\
\end{array}$ & Professional ethics \\
\hline $\begin{array}{l}\text { Effective } \\
\text { organisation } \\
\text { of teaching- } \\
\text { learning process }\end{array}$ & $\begin{array}{l}\text { Effective use of digital } \\
\text { technology }\end{array}$ & $\begin{array}{l}\text { Planning and prepping skills } \\
\text { Skilful application of teaching } \\
\text { methods } \\
\text { Creating a learning environment } \\
\text { Creativity }\end{array}$ \\
\hline
\end{tabular}


Pedagogical digital competence is a set of knowledge, skills and attitudes in the critical use of digital tools in planning, organising and evaluating a student-centered and inclusive learning process based on a teacher's (1) knowledge of effective use of digital technologies for organising teaching and learning while assessing and selecting suitable digital solutions, (2) skills for organising student learning in both digital and classroom environments, reflecting on his/her own and students' benefits in using various forms of cooperation, (3) positive attitude and openness to the use of new pedagogical and digital solutions in the development of their professional activities.

\section{Pedagogical digital competence concept model}

Based on the results of the literature review the author developed a pedagogical digital competence concept model (see Fig. 2), explaining in more detail each stage of pedagogical-digital competence and its role in pedagogical digital competence acquisition. The structure of the model is adapted from Krumsvik's (2011) teachers' digital competence model.

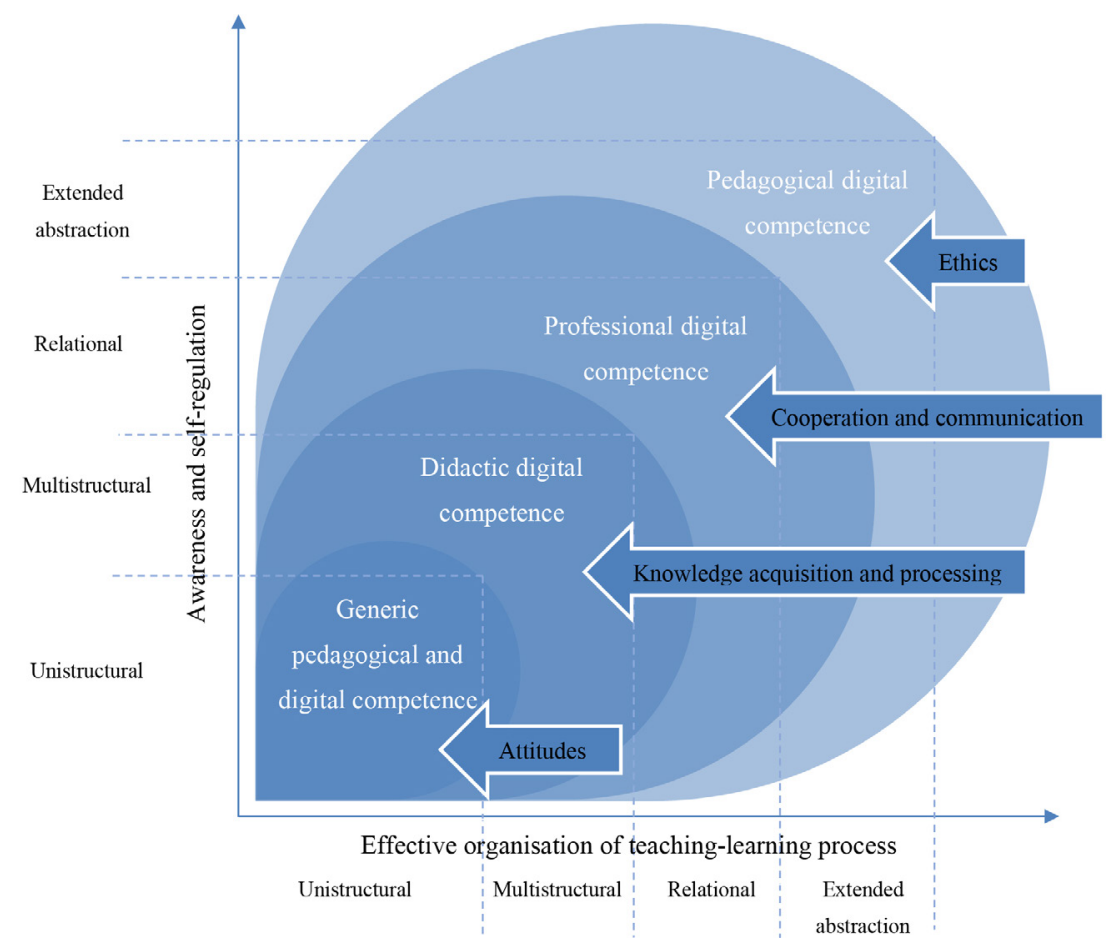

Figure 2. Pedagogical digital competence development in teacher education (concept model developed by the author) 
The concept model is based on two pillars: (1) development of teacher's awareness and self-regulation, as well as (2) improvement of effective teaching work organisation. Each of these aspects develops as the teacher's knowledge and experience of pedagogical concepts and the use of digital technology evolves and expands. To illustrate this development, the SOLO (Structure of the Observed Learning Outcome) taxonomy model (Biggs, 1999) was used, which adapts to the organisation of the teaching process at the university. The SOLO taxonomy distinguishes 4 levels of knowledge construction (Biggs \& Collins, 1982; Biggs, 1999): unistructural operation, multistructural operation, relational operation, extended abstraction.

Accordingly, the development of pedagogical digital competence can be described in 4 stages:

1. Generic pedagogical and digital competence, which is based on attitude formation by exploring one's pedagogical self and acquiring basic knowledge about the pedagogical process as well as about the role of digital technologies in it. Assuming that any teacher in today's world has experience interacting with digital technologies and basic software, the teacher has some experience and understanding of digital technologies (Ottestad et al., 2014). As digital competence develops, the teacher expands his/her general knowledge and skills in the use of digital technologies and the understanding of pedagogical concepts by identifying and researching separate and self-relevant ideas (Biggs, 1999; Krumsvik, 2011). The teacher's main task is extending their awareness about the role of digital technologies and education in their lives, as well as identifying their existing knowledge and skills along with their shortcomings. To achieve this, teachers should mutually share their experiences and individually reflect on their own experience and knowledge acquisition (Kelentrić et al., 2017). As a result, the teacher should reflect on their own understanding of a successful learning process and the role of digital technologies in it.

2. Didactic digital competence is related to the acquisition and processing of knowledge. It means acquiring fundamental pedagogical and digital knowledge about theories and tools that can help to implement the teacher's pedagogical vision in a technology enhanced learning environment (Krumsvik, 2011; Ottestad et al., 2014). In this process a person becomes aware of him or herself as a teacher, as well as of his/ her approach and goals in his/her professional work. Thus, the teacher purposefully expands his/her knowledge, supplementing his/her ideas with facts, theories and resources. The teacher explores various digital technologies relevant to modern education and begins to consider how they can help or interfere with the learning process. To support the development of a teacher's knowledge and experience, it is possible 
to organise pedagogical observation to demonstrate the application of pedagogical concepts or digital technologies in the educational process, as well as to diversify the forms and methods of organising teacher learning activities (Røkenes \& Krumsvik, 2014). As a result, teachers can model simple learning situations by combining knowledge in particular aspects.

3. Professional digital competence is related to active application of a teacher's theoretical knowledge in a variety of social situations. This includes organising students' learning activities and their professional development in both the digital and school environment. Professional digital competence is most relevant when the teacher sees the interrelationships between the concepts and he/she knows and applies them widely in their work (Kelentrić et al., 2017). The teacher continues to improve his/her knowledge and skills in both pedagogical competence and digital literacy, for example, by learning class management techniques, methods and tools for assessing student learning outcomes, organising cooperation with parents, etc. (Mishra \& Koehler, 2006). Most importantly, the teacher gains practical experience working with the class and solving various learning situations, as well as collaborating with other teachers and engaging in various school activities (Heath, 2018; Wilkins, 2008). Therefore, the teacher also uses digital technologies as a collaboration and communication tool for planning, organising and evaluating his/her professional activity as well as organising the teaching-learning process.

4. Pedagogical digital competence includes high-level evaluation and decision-making skills, where the teacher is able to analyse the impact of digital technologies on students' learning and their professional activities, thus creating new ideas and tools for addressing different educational situations. Pedagogical digital competence entails that the teacher is able to abstract from his/her direct knowledge of the teaching-learning process and from his/her professional work, creating new ways and solutions for teaching and learning (Ottestad et al., 2014). The teacher develops new teaching materials (both analogue and digital) and uses complex theoretical knowledge in difficult pedagogical situations (Kabakci Yurdakul, 2018; Nykes, 2018). However, awareness of ethical aspects is also important in this stage, as the teacher is able to consider not only how to use digital technologies and organise students' learning activities, but also to take into account how these technologies and tasks affect students' learning achievements, learning motivation, attitude, personality, etc., as well as to influence the work of the teacher himself (Krumsvik, 2011). Therefore, the aspects of ethics in education - inclusiveness, confidentiality, responsibility, 
values - must be considered at this stage of pedagogical digital competence, as the teacher is able to reason about best solutions that can be implemented.

\section{Pedagogical digital competence acquisition plan in teachers' professional bachelor study programme}

During empirical research, the study course descriptions mapping was conducted (Joyner, 2016). Teacher professional bachelor study programme consists of seven study sub-programs and compulsory course plan. In the research the course descriptions of these seven study sub-programs and compulsory courses were analysed. A total of 201 study course descriptions, and within them 1553 learning outcomes, were analysed. The mapping tool was developed based on the descriptions of the four stages of pedagogical digital competence acquisition. At each stage of pedagogical digital competence, the most important aspects of its successful acquisition were defined. Accordingly, for each pedagogical digital competence stage learning outcomes were formulated for acquiring digital literacy and pedagogical competence. In order to assess the depth of the defined learning outcomes, the SOLO taxonomy model was used, distinguishing comprehension levels for each outcome.

The overall planning of study courses in different study sub-programmes is different both from the viewpoint of study content distribution between pedagogical digital competence stages and from the viewpoint of its acquisition levels. The least planned stages of pedagogical digital competence were the generic pedagogical and digital competence stage and the pedagogical digital competence stage (see Tables 3 and 4). At the same time, unistructural activity is the most actualised pedagogical digital competence level, as opposed to extended abstraction, which was the least actualised. However, it is important to highlight the successful planning of compulsory courses, which, when included in the acquisition of each study sub-programme, balances both the stages and the levels of acquisition of pedagogical digital competence.

The planning of teachers' pedagogical knowledge, skill and attitude acquisition in the analysed teacher education sub-programmes differs in terms of the content included in each sub-programme; however, in terms of content distribution between stages and levels of pedagogical-digital competence, the content is distributed similarly in all study sub-programmes. The least pedagogical competence is reflected in the generic pedagogical and digital competence stage; consequently the actualisation of teachers' previous knowledge and experience before the acquisition of new knowledge and skills is not fully planned. 
Table 3. Learning objective distribution between stages of pedagogical digital competence

\begin{tabular}{|c|c|c|c|c|c|c|c|c|c|c|}
\hline & 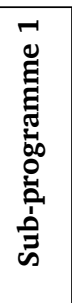 & 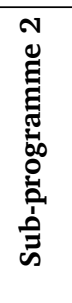 & 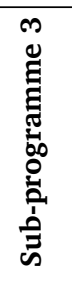 & 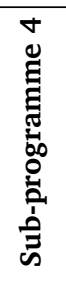 & 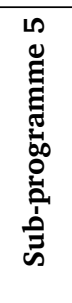 & 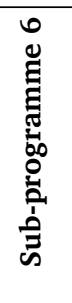 & 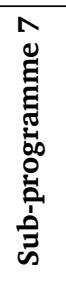 & 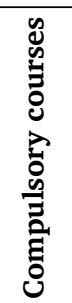 & 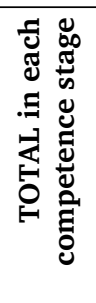 & $\%$ \\
\hline $\begin{array}{l}\text { 1. Generic } \\
\text { pedagogical and } \\
\text { digital competence }\end{array}$ & 21 & 9 & 13 & 18 & 1 & 3 & 0 & 6 & 71 & $4.6 \%$ \\
\hline $\begin{array}{l}\text { 2. Didactic digital } \\
\text { competence }\end{array}$ & 143 & 91 & 101 & 161 & 133 & 249 & 177 & 33 & 1088 & $70.1 \%$ \\
\hline $\begin{array}{l}\text { 3. Professional } \\
\text { digital competence }\end{array}$ & 42 & 16 & 29 & 22 & 29 & 28 & 13 & 47 & 226 & $14.6 \%$ \\
\hline $\begin{array}{l}\text { 4. Pedagogical } \\
\text { digital competence }\end{array}$ & 38 & 13 & 11 & 23 & 15 & 16 & 14 & 38 & 168 & $10.8 \%$ \\
\hline $\begin{array}{l}\text { TOTAL in a study } \\
\text { subprogramme }\end{array}$ & 244 & 129 & 154 & 224 & 178 & 296 & 204 & 124 & 1553 & \\
\hline
\end{tabular}

Table 4. Learning objective distribution between levels of pedagogical digital competence

\begin{tabular}{|c|c|c|c|c|c|c|c|c|c|c|}
\hline & 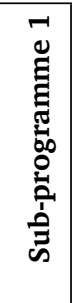 & 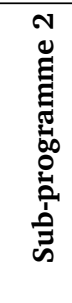 & 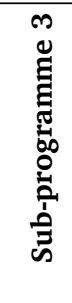 & 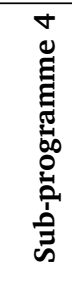 & 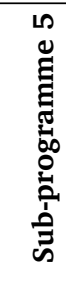 & 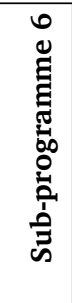 & 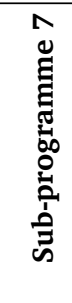 & 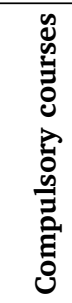 & 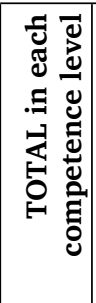 & $\%$ \\
\hline Unistructural & 87 & 65 & 58 & 119 & 66 & 136 & 125 & 39 & 695 & $44.8 \%$ \\
\hline $\begin{array}{l}\text { Multistructural } \\
\text { operation }\end{array}$ & 61 & 33 & 28 & 44 & 56 & 62 & 43 & 24 & 351 & $22.6 \%$ \\
\hline Relational & 70 & 22 & 55 & 58 & 44 & 78 & 26 & 35 & 388 & $24.9 \%$ \\
\hline Extended abstraction & 26 & 9 & 13 & 3 & 16 & 20 & 10 & 26 & 123 & $7.9 \%$ \\
\hline $\begin{array}{l}\text { TOTAL in a study } \\
\text { subprogramme }\end{array}$ & 244 & 129 & 154 & 224 & 178 & 296 & 204 & 124 & 1553 & \\
\hline
\end{tabular}


In all study sub-programmes, great attention is paid to particular subject content knowledge, which suppresses the acquisition of pedagogical knowledge and skills. A successful aspect which is widely included in all study sub-programmes is the activities where students plan and solve various simple and complex pedagogical situations. However, there is insufficiently planned student cooperation and communication skill promotion, not only regarding cooperation with fellow students during the study courses, but also in terms of gaining experience and skills for cooperation with education professionals, parents and school management. Given that the analysed study sub-programmes do not pay enough attention to the implementation of generic pedagogical and digital competence, there is a risk that future teachers in their professional work will stick to the model of pedagogical process that they have experienced and will not be able to fully and reasonably assess the advantages and disadvantages of such an approach.

The pedagogical digital competence acquisition planning in the analysed study sub-programmes mainly differs due to varying digital literacy planning. The plan for the acquisition of digital literacy is based on unistructural operations, where students are often expected to create and present independent study papers using digital technologies (mostly presentations). However, most study sub-programmes also plan to teach teachers the use of digital technologies in the organisation of the teaching-learning process, the use of certain digital tools and the development of digital teaching materials. In the analysed study programme the most significant shortcomings in the acquisition of digital literacy are:

1) insufficient involvement of teachers' existing knowledge, skills and attitudes,

2) incomplete digital literacy acquisition process, which lacks experimentation with different digital technologies and tools,

3) poor attention to teacher cooperation skills in the digital environment and

4) insufficient understanding of how to develop student self-directed learning in a digital space.

\section{Discussion}

The concept model of pedagogical digital competence was adjusted (see Fig. 3) primarily to reflect the proportional distribution of pedagogical digital competence acquisition stages: (1) the share of the generic pedagogical and digital competence stage was reduced, (2) the segment of the didactic digital competence stage was increased, (3) the share of professional digital competence versus professional digital competence dimension was increased. 
Secondly, in the context of pedagogical competence, (1) the knowledge of the subject content knowledge was included in the last three stages of pedagogical digital competence and (2) the aspect of educational management was included in last two stages of pedagogical digital competence.

Thirdly, the division of pedagogical competence and digital literacy was emphasised in all stages of pedagogical digital competence, determining an approximate ratio between the amount of pedagogical competence and digital literacy acquisition - two thirds of the study content should consist of topics related to pedagogical competence, while one third of the study content should be devoted to digital literacy.

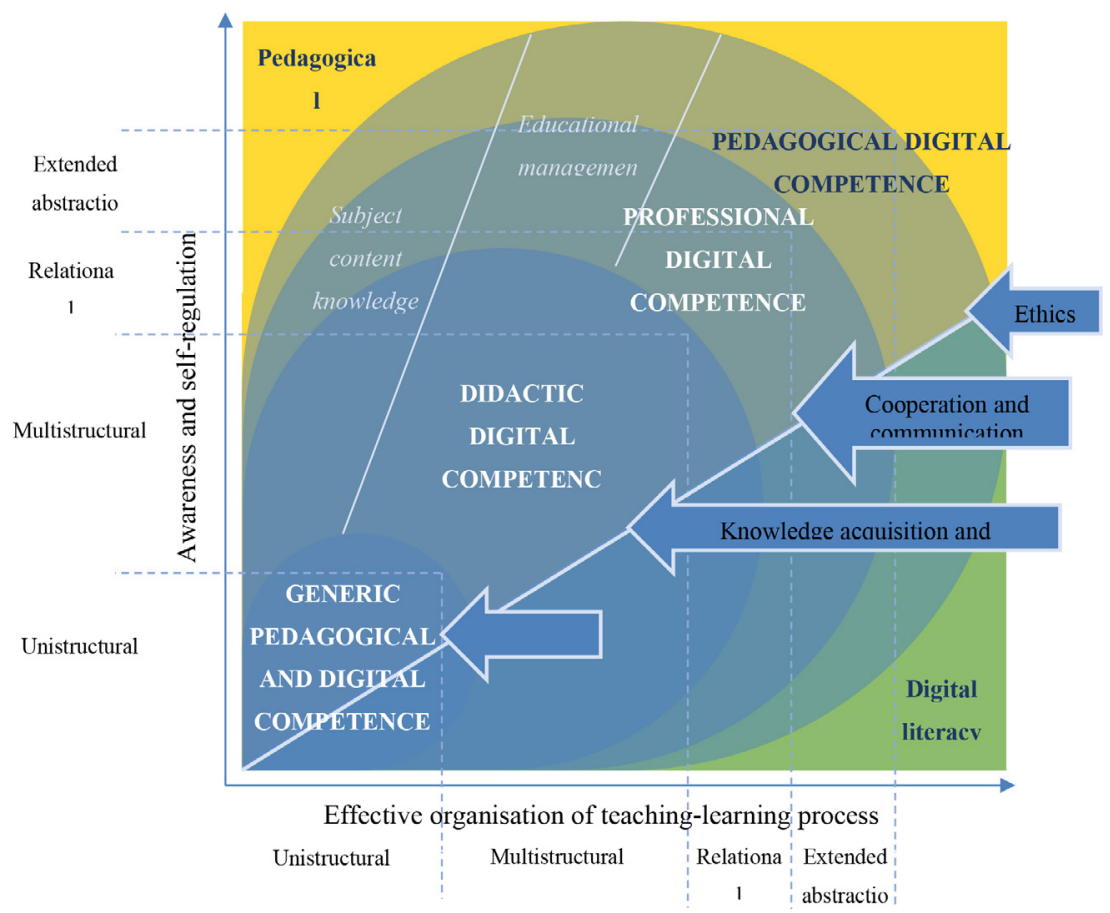

Figure 3. Improved pedagogical digital competence concept model

\section{Conclusions}

The concept of digital skills today is relevant in all areas of life, forcing the education industry to actively seek solutions for teaching digital skills in the context of society as a whole. Nevertheless, digital literacy at different levels of education is still not sufficiently implemented due to deficient resources, knowledge and skills. The study analyses pedagogical digital competence as a basis for successful acquisition of digital literacy 
in teacher education, supporting and improving teachers' skills to organize a technology enhanced learning process. The aim of the research is to study pedagogical digital competence and its acquisition plan in the teacher education programme, looking for answers to the questions: (1) what are the components of pedagogical digital competence that a teacher needs in their work and (2) how is the acquisition of pedagogical digital competence in the teacher education programme planned?

As a result of the literature review, it was concluded that there is a consensus among researchers that the solution to successful digital literacy implementation in teacher education is an integrated approach. In this study digital literacy was used as a cross-cutting competence in the acquisition of pedagogical competence. As a result of the literature review a concept model of pedagogical digital competence was developed, which characterises the development of pedagogical digital competence in 4 stages:

1) Generic pedagogical and digital competence based on the identification of one's existing experience in pedagogical situations and the use of digital technologies, as well as on the acquisition of personally relevant knowledge on pedagogical topics and digital technologies.

2) Didactic digital competence related to the acquisition and processing of knowledge, acquiring a base of facts, theories and tools that help to implement the teacher's pedagogical vision in the creation of a technology-enhanced learning environment.

3) Professional digital competence is related to the application of a teacher's theoretical knowledge in various social situations, participation in the organisation of students' learning activities and continuation of their professional development in both the digital and school environment.

5) Pedagogical digital competence describes a teacher who is able to independently organise teaching work, evaluate the implementation technology-rich learning in his/her classroom and school, make suggestions and improve own and school's professional work, as well as develop new teaching materials (both analogue and digital) for students to improve the learning environment.

In the empirical study, carrying out the analysis of seven teacher education sub-programmes and compulsory courses, it was concluded that the overall study course planning in different study sub-programmes differs both in pedagogical digital competence stages and in its levels. The pedagogical digital competence acquisition planning in the analysed study programme mainly varies between different sub-programmes due to contrasting digital literacy acquisition planning. The digital literacy plan is based on acquiring general knowledge about the daily use of digital technologies. However, in most study sub-programmes expected for students to acquire the use of 
educational technologies in the organisation of the teaching-learning process, learning to use certain digital tools and develop digital teaching materials. In the context of both pedagogical competence and digital literacy, generic digital and pedagogical competence is the least disclosed stage of pedagogical digital competence, therefore the attention to teachers' previous knowledge and experience before the acquisition of new knowledge and skills is not fully overseen. In the implementation of pedagogical competence in all study sub-programmes, great attention is paid to the subject content knowledge, which suppresses the planned acquisition of pedagogical knowledge and skills. The promotion of teachers' cooperation skills is insufficiently planned, since students should cooperate not only with study members, but also by gaining experience and skills cooperating with professional teachers, students, their parents and the school management team.

Although it was concluded that the implementation of pedagogical digital competence in the analysed study programme is not fully implemented, adjustments were made in the concept model of pedagogical digital competence based on the tendencies observed in analysed study course descriptions. Primarily, the proportional distribution of pedagogical digital competence stages was adjusted according to the planned amount of study content reflected in each stage, and secondly, the concept model reflects a more detailed aspect of pedagogical competence, including (1) subject content knowledge relevant to the last three pedagogical digital competence stages, (2) aspects of educational management that are relevant in the last two stages of pedagogical digital competence acquisition, (3) highlighting the ratio between the amount of pedagogical competence (two thirds of the study content) and digital literacy (one third of the study content) acquisition.

\section{References}

Altan, S., Lane, J. F., \& Dottin, E. (2019). Using Habits of Mind, Intelligent Behaviors, and Educational Theories to Create a Conceptual Framework for Developing Effective Teaching Dispositions. Journal of Teacher Education, 70(2), 169-183. https://journals. sagepub.com/doi/10.1177/0022487117736024

Biezā, K. E. (2020). Digital Literacy: Concept and Definition. International Journal of Smart Education and Urban Society (IJSEUS), 11(2), 1-15. http://doi.org/10.4018/ IJSEUS.2020040101

Biggs, J. B. (1999). Teaching for Quality Learning at University. SRHE and Open University Press.

Biggs, J. B., \& Collins, K. F. (1982). Evaluating the Quality of Learning: The SOLO Taxonomy (Structure of the Observed Learning Outcome). Academic Press. Retrieved from: https://books.google.lv/books

Ekmekçi, E. (2018). Examination of Studies Regarding Pre-Service Efl Teachers' Technological Pedagogical Content Knowledge (Tpack) in Turkey. International Journal 
of Eurasia Social Sciences / Uluslararasi Avrasya Sosyal Bilimler Dergisi, 9(34), 2180-2193. Retrieved from: http://web.a.ebscohost.com/ehost

European Commission (2018). Digital Competence Framework for Educators (DigCompEdu). Retrieved from: https://ec.europa.eu/jrc/en/printpdf/137812

European Commission/EACEA/Eurydice (2018). Teaching Careers in Europe: Access, Progression and Support. Eurydice report. Publications Office of the European Union. Retrieved from: https://op.europa.eu/lv/publication-detail

European Commission/EACEA/Eurydice (2019). Digital Education at School in Europe. Eurydice report. Publications Office of the European Union. Retrieved from: https:// www.viaa.gov.lv/library

Farinde-Wu, A., Glover, C., \& Williams, N. (2017). It's Not Hard Work; It's Heart Work: Strategies of Effective, Award-Winning Culturally Responsive Teachers. Urban Review, 49(2), 279-299. DOI: 10.1007/s11256-017-0401-5

Flick, U. (2007). Concepts of triangulation. Qualitative Research kit: Managing quality in qualitative research. SAGE Publications, 38-54. DOI: 10.4135/9781849209441

From, J. (2017). Pedagogical Digital Competence-Between Values, Knowledge and Skills. Canadian Center of Science and Education, 7(2), 43-50. Retrieved from: https:// files.eric.ed.gov/fulltext

Hayes, N., \& Filipović, K. (2018). Nurturing 'buds of development': from outcomes to opportunities in early childhood practice. International Journal of Early Years Education, 26(3), 220-232. Retrieved from: http://web.a.ebscohost.com/ehost

Heath, M. K. (2018). What kind of (digital) citizen? A between-studies analysis of research and teaching for democracy. International Journal of Information \& Learning Technology, 35, 342-356. https://doi.org/10.1108/IJILT-06-2018-0067

Instefjord, E. J., Munthe, E. (2017). Educating digitally competent teachers: A study of integration of professional digital competence in teacher education. Elsevier, 67, 37-45.

Cui, J. (2018). An assessment of the pedagogical management competencies of mandarin language teachers in selected Chinese schools. Indian Journal of Health \& Wellbeing, 9(10-12), 977-981.Retrieved from: http://web.a.ebscohost.com/ehost

Johnson, B., \& Christensen, L. (2012). Educational Research: Quantitative, Qualitative, and Mixed Approaches ( $4^{\text {th }}$ ed.). SAGE.

Jons, L. (2008). Till-tal och an-svar: En konstruktion av pedagogisk hållning. US-AB Printcenter.

Joyner, H. S. (2016). Curriculum Mapping: A Method to Assess and Refine Undergraduate Degree Programs. Journal of Food Science Education, 15, 83-100. Retrieved from: https:// onlinelibrary.wiley.com/doi

Kabakci Yurdakul, I. (2018). Modeling the relationship between pre-service teachers' TPACK and digital nativity. Educational Technology Research \& Development, 66(2), 267281. Retrieved from: http://web.a.ebscohost.com/ehost

Kelentrić, M., Helland, K., \& Arstorp, A. T. (2017). Professional Digital Competence Framework for Teachers in Norway. Norwegian Centre for ICT in Education. Retrieved from: https://www.researchgate.net/publication

Koehler, M. J., Mishra, P., Kereluik, K., Shin, T. S., \& Graham, C. R. (2014) The technological pedagogical content knowledge framework. In: J. M. Spector (Ed.), Handbook of research on educational communications and technology (pp. 101-111). Springer. 
Krumsvik, R. (2011). Digital competence in the Norwegian teacher education and school. Högre Utbildning, 1(1), 39-51. Retrieved from: https://www.researchgate.net/ publication

Mishra, P., \& Kohler, M. J. (2006). Technological Pedagogical Content Knowledge: A Framework for Teacher Knowledge. Teachers College Record, 108(6), 1017-1054.

Nyikes, Z. (2018). Contemporary Digital Competency Review. Interdisciplinary Description of Complex Systems, 16(1), 124-131. Retrieved from: http://web.a.ebscohost.com/ehost

Ottestad, G., Kelentrić, M., Guðmundsdóttir, G. (2014). Professional Digital Competence in Teacher Education. Nordic Journal of Digital Literacy, 9, 243-249. Retrieved from: https://www.researchgate.net/publication

Pekkarinen, V., \& Hirsto, L. (2017). University Lecturers' Experiences of and Reflections on the Development of Their Pedagogical Competency. Scandinavian Journal of Educational Research, 61(6), 735-753. Retrieved from: http://web.a.ebscohost.com/ ehost

Redecker, C. (2017). European Framework for the Digital Competence of Educators: DigCompEdu. Publications Office of the European Union. ISBN 978-92-79-73494-6. DOI:10.2760/159770, JRC107466

Reimer, F. M., \& Schleiche, A. (2020). A framework to guide an education response to the COVID-19 Pandemic of 2020. OECD Library. Retrieved from: https://read.oecdilibrary.org/view

Røkenes, F. M., \& Krumsvik, R. (2014). Development of Student Teachers' Digital Competence in Teacher Education - A Literature Review. Nordic Journal of Digital Literacy, 9, 250-280.

Sinkovics, N. (2018). Pattern matching in qualitative analysis. In C. Cassell, A. L. Cunliffe, \& G. Grandy (Eds.), The sage handbook of qualitative business and management research methods (pp. 468-484). SAGE. DOI: 10.4135/9781526430236

Soysal, Y., \& Radmard, S. (2018). An Exploration of Turkish Prospective Teachers' Teaching Competencies through the Analysis of Their Pedagogical Content Knowledge Documentations. Journal of Education, 198(2), 165-180. Retrieved from: https:// journals.sagepub.com/doi

Spante, M., Sofkova Hashemi, S., Lundin, M., \& Algers, A. (2018). Digital competence and digital literacy in higher education research: Systematic review of concept use. Cogent Education, 5, 1. DOI: 10.1080/2331186X.2018.1519143

Trilling, B., \& Fedel, C. (2009). 21 ${ }^{\text {st }}$ Century Skills: learning for life in our times. HB Printing. Retrieved from: https://epdf.pub/21st-century-skills-learning-for-life-in-ourtimes.html

UNESCO. COVID-19 Educational Disruption and Response. Retrieved from: https:// en.unesco.org/covid19

Wilkins, J. L. M. (2008). The relationship among elementary teachers' content knowledge, attitudes, beliefs, and practices. Journal of Mathematics Teacher Education, 11, 139-164. https://doi.org/10.1007/s10857-007-9068-2

Yürekli Kaynardağ, A. (2019). Pedagogy in HE: does it matter? Studies in Higher Education, 44(1), 111-119. Retrieved from: https://www.tandfonline.com/doi 